\title{
First report of the parasitoid Pachycrepoideus vindemmiae (Rondani, 1875) (Hymenoptera: Pteromalidae) parasitizing Synthesiomyia nudiseta (Van der Wulp, 1883) (Diptera: Muscidae)
}

\author{
C. H. Marchiori ${ }^{a *}$ and L. M. F. Borges ${ }^{b}$ \\ anstituto Federal Goiano - IF Goiano, Universidade Federal de Goiás - UFG, \\ Rua 235, s/n, Setor Universitário, CEP 74605050, Goiânia, GO, Brazil \\ bInstituto de Patologia Tropical e Saúde Pública - IPTSP, Universidade Federal de Goiás - UFG, \\ Rua 235, s/n, Setor Universitário, CEP 74605050, Goiânia, GO, Brazil \\ *e-mail: chmarchiori@yahoo.com.br
}

Received: March 15, 2016 - Accepted: May 19, 2016 - Distributed: August 31, 2017

The hosts of Pteromalidae include Hemiptera, Neuroptera, Coleoptera, Lepidoptera, Diptera, Siphonaptera, Hymenoptera, Dermaptera and Homoptera. Pteromalidae attack eggs, larvae, pupae or, rarely, adults. The main contribution of pteromalids towards insect control is in relation to muscoid flies, especially house flies and stable flies (Gauld and Bolton, 1988; Hanson and Gauld, 1995).

The adults of some species of the family Muscidae are vectors, through their bite or in a passive manner, for the pathogens of diseases such as typhoid fever, dysentery, anthrax and African sleeping sickness. House flies overwinter in either the larval or pupal stage under manure piles or in other protected locations. This is the most common insect family found on pig and poultry farms, in horse stables and on ranches (Renaud et al., 2012).

Synthesiomyia nudiseta (Van der Wulp, 1883) (Diptera: Muscidae) is a fly with Neotropical geographical distribution. In Brazil, it shows preference for inhabited areas, which makes this fly a potential vector for pathogens (Greenberg, 1971; Aruna et al., 2011; Velásquez et al., 2013).

Pachycrepoideus vindemmiae (Rondani, 1875) (Hymenoptera: Pteromalidae) is to be a solitary parasitoid that controls a great number of Diptera in the families Anthomyiidae, Calliphoridae, Muscidae, Sarcophagidae, Tachinidae and Tephritidae. This species presents diversified (cosmopolitan) distribution and it has been found in North America and Africa (Hanson and Gauld, 1995).

The objective of this paper was to report a new host for the parasitoid $P$. vindemmiae, which was collected in the urban region of Goiânia, in the central part of the state of Goiás, Brazil.

The experiment was conducted in the urban area of Goiânia, in the central part of the state of Goiás, Brazil. The flies were collected by using traps, made of dark cans measuring $19 \mathrm{~cm}$ in height and $9 \mathrm{~cm}$ in diameter, with two openings resembling blinders, located in the lowest third of the can, to allow flies to enter. The top of the can was connected to a nylon funnel that was open at both ends, with the base pointing down. This was wrapped in plastic bags, so that when they were removed, the flies and parasitoids could be collected. The following items were used as baits: human feces, cattle kidneys, cattle liver, chicken and fish which were placed inside the cans, over a layer of earth. Five traps were used and they were hung on trees at a height of one meter above the ground, two meters apart from each other.

The insects collected were taken to the laboratory, sacrificed with ethyl ether and kept in $70 \%$ alcohol for further identification. To obtain the parasitoids, the contents of the traps were placed in plastic containers with a layer of sand for use as a substrate for transformation of the larvae into pupae. This sand was sifted after being in the fields for 15 days and the pupae were extracted from it and were individually placed in gelatin capsules (number 00) in order to obtain the flies and/or parasitoids.

The species were stored in the Biology Laboratory of Institute of Tropical Pathology and Public Health. The species identification was performed by one of the authors.

The total percentage parasitism was calculated by means of the number of pupae parasitized, divided by the total number of pupae collected, and multiplied by 100 .

Between January and May 2014, two specimens of $P$. vindemmiae were collected from 26 pupae of $S$. nudiseta . The percentage parasitism observed was $7.7 \%$. The percentage parasitism can also be correlated with the parasitoid's search capacity and with the availability of resources.

These dipterous insects are potential mechanical vectors for etiological agents such as viruses, bacteria, protozoan cysts and helminth eggs (Greenberg, 1971; Marchiori, 2006). The occurrence, distribution and prevalence of these dipterous insects in metropolitan areas are factors of great public health importance. In rural areas, these insects can cause decreased egg production and animal diseases, and they constitute a nuisance for human populations close to the breeding sites (Couri and Barros, 2010; Ekanem et al., 2013; Marchiori, 2007; Marchiori et al., 2014).

Pachycrepoideus vindemmiae is considered a parasitoid of pupae of a great number of Diptera, including species of the genera Anastrepha, Calliphora, Ceratitis, Chrysomya, Drosophila, Fannia, Haematobia, Hylemya, Lucilia, Megaselia, Musca, Ophyra, Ornidia, Oxysarcodexia, Palaeosepsis, Paratheresia, Phaenicia, Phormia, Poecilosomella, Peckia, 
Rhagoletis, Sarcophagula, Sarcodexia and Zaprionus (Hanson and Gauld, 1995; Marchiori, 2000; Marchiori and Barbaresco, 2007; Marchiori et al., 2003, 2013).

One possibility for controlling these flies is to use natural regulators such as parasitoids, which are agents responsible for reducing the synanthropic fly populations.

\section{References}

ARUNA, D., ABU, H.A., KUMARA, T.K. and CHE, S.M.R., 2011. Life table of Synthesiomyia nudiseta (Van der Wulp) (Diptera: Muscidae) under uncontrolled laboratory environments: a preliminary study. Tropical Biomedicine, vol. 28, no. 3, pp. 524-530. PMid:22433881.

COURI, M.S. and BARROS, G.P.S., 2010. Diptera hosts of Stylogaster Macquart (Diptera: Conopidae) from Madagascar and South Africa. Revista Brasileira de Entomologia, vol. 54, no. 3, pp. 361-366. http://dx.doi.org/10.1590/S0085-56262010000300003.

EKANEM, M.S., IDIONG, M.O. and USUA, E.J., 2013. Synanthropic indices and baits preferences of common nonbiting dipterous (Diptera: Cyclorrhapha) of Akwa Ibom State, Nigeria. International Journal of Applied Science and Technology, vol. 5, pp. 192-197.

GAULD, I.D. and BOLTON, D.B., 1988. The Hymenoptera. Oxford: Oxford University Press. 893 p. vol. 1.

GREENBERG, B., 1971, Dipterous and disease: ecology, classification and biotic association. New Jersey: Princeton University Press. 846 p. vol. 3.

HANSON, P.E. and GAULD, I.D., 1995. The Hymenoptera of Costa Rica. Oxford: Oxford University Press. 893 p. vol. 1.

MARCHIORI, C.H. and BARBARESCO, L.F., 2007. Occurrence of Pachycrepoideus vindemmiae (Rondani, 1875) (Hymenoptera: Pteromalidae) as a parasitoid of Megaselia scalaris (Loew, 1866) (Diptera: Phoridae) in Brazil. Brazilian Journal of Biology $=$ Revista Brasileira de Biologia, vol. 67, no. 3, pp. 577-578. PMid:18094843. http://dx.doi.org/10.1590/S1519-69842007000300025.

MARCHIORI, C.H., 2000. Parasitóides de estágios imaturos de dípteros sinantrópicos coletados em vários ambientes em Itumbiara-GO. Acta Scientiarum, vol. 22, pp. 655-661.
MARCHIORI, C.H., 2006. Study of a community of flies at different altitudes in the Serra of Caldas Novas Park, Goiás, Brazil. Brazilian Journal of Biology $=$ Revista Brasileira de Biologia, vol. 66, no. 3, pp. 849-851. PMid:17119832. http:// dx.doi.org/10.1590/S1519-69842006000500010.

MARCHIORI, C.H., 2007. Gnathopleura quadridentata Wharton, 1986 (Hymenoptera; Braconidae; Alysiinae) and their hosts collected in different substrates in Caldas Novas, Goiás. Brazilian Journal of Biology $=$ Revista Brasileira de Biologia, vol. 67, no. 1, pp. 101-103. PMid:17505755. http://dx.doi.org/10.1590/ S1519-69842007000100013.

MARCHIORI, C.H., BORGES, L.M.F. and FERREIRA, L.L., 2013. Hosts of the Parasitoid Pachycrepoideus vindemmiae (Rondani) (Hymenoptera: Pteromalidae) of Medical-Veterinary and Economic Importance Collected in the State of Goiás, Brazil. American Journal of Life Sciences, vol. 1, no. 5, pp. 228-231. http://dx.doi.org/10.11648/j.ajls.20130105.14.

MARCHIORI, C.H., BORGES, L.M.F. and FERREIRA, L.L., 2014. Parasitoids of dipterous collected in cattle dung in the Regions Southern and Central of Goiás, Brazil. Advances in Entomology, vol. 2, no. 1, pp. 20-23. http://dx.doi.org/10.4236/ae.2014.21004.

MARCHIORI, C.H., PEREIRA, L.A. and SILVA FILHO, O.M., 2003. Primeiro relato do parasitóide Pachycrepoideus vindemmiae (Rondani) (Hymenoptera: Pteromalidae) parasitando pupas de Sarcodexia lambens Wiedemann (Diptera: Sarcophagidae). Ciência Rural, vol. 33, no. 1, pp. 73-175. http://dx.doi.org/10.1590/ S0103-84782003000100029.

RENAUD, A.K., SAVAGE, J. and ADAMOWICZ, S.J., 2012. DNA barcoding of northern Nearctic Muscidae (Diptera) reveals high correspondence between morphological and molecular species. BMC Ecology, vol. 12, no. 1, pp. 24-24. PMid:23173946. http:// dx.doi.org/10.1186/1472-6785-12-24.

VELÁSQUEZ, Y., IVORRA, T., GRZYWACZ, A., MARTÍNEZSÁNCHEZ, A., MAGAÑA, C., GARCÍA-ROJO, A. and ROJO, S., 2013. Larval morphology, development and forensic importance of Synthesiomyia nudiseta (Diptera: Muscidae) in Europe: a rare species or just overlooked? Bulletin of Entomological Research, vol. 103, no. 1, pp. 98-110. PMid:22929039. http://dx.doi. org/10.1017/S0007485312000491. 